\title{
Fases cementantes obtenidas a partir de residuos sólidos urbanos
}

\section{Obtaining cementitious material from municipal solid waste}

\author{
$\underline{\text { S. Goñi }}^{(*)}$, A. Guerrero $^{(*)}$ y A. Macías ${ }^{(*)}$
}

Recepción/Received: 24-II-06

Aceptación/Accepted: 13-VII-06

\section{RESUMEN}

El principal objetivo del trabajo ha sido determinar la viabilidad del uso de las cenizas y escorias procedentes de la incineración de residuos sólidos urbanos, como materia prima secundaria para la obtención de fases cementantes. Para ello se han empleado los residuos generados en dos tipos de incineradoras españolas de residuos sólidos urbanos: la incineradora de Valdemingómez y la incineradora de Melilla. Se ha estudiado la transformación de los residuos, sin tratamiento previo, en función de la temperatura de calentamiento (desde $800^{\circ} \mathrm{C}$ hasta $1.200{ }^{\circ} \mathrm{C}$ ), así como la influencia del lavado de los residuos con alto contenido en $\mathrm{NaCl}$ y $\mathrm{KCl}$ en la formación de fases obtenidas a las diferentes temperaturas de calcinación. Las fases obtenidas fueron caracterizadas por difracción de rayos $X$ y área superficial por el método $B E T-N_{2}$.

Palabras clave: incineración de residuos sólidos urbanos, materia prima secundaria, temperatura, caracterización.

\section{SUMMARY}

The primary purpose of the present study was to determine the viability of using incinerator ash and slag from municipal solid waste as a secondary source of cementitious materials. The combustion products used were taken from two types of Spanish MSW incinerators, one located at Valdemingómez, in Madrid, and the other in Melilla, with different incineration systems: one with fluidised bed combustion and other with mass burn waterwall. The effect of temperature (from 800 to $1,200^{\circ} \mathrm{C}$ ) on washed and unwashed incinerator residue was studied, in particular with regard to phase formation in washed products with a high $\mathrm{NaCl}$ and $\mathrm{KCl}$ content. The solid phases obtained were characterized by $X$-ray diffraction and $B E T-N_{2}$ specific surface procedures.

Keywords: incineration of municipal solid waste, secondary raw material, temperature, characterization.

\section{INTRODUCCIÓN}

Una de las soluciones más ventajosas, implantada hace más de 30 años para la gestión de los residuos sólidos domésticos generados en las ciudades, es sin duda la incineración en hornos con y sin recuperación de energía.

\section{INTRODUCTION}

Incineration in furnaces with and without energy recovery, introduced over 30 years ago, is indisputably one of the most satisfactory solutions for handling the domestic solid waste generated in cities. Nonetheless,

(*) Instituto de Ciencias de la Construcción Eduardo Torroja (CSIC), Madrid (España). 
Aunque la incineración de dichos residuos conlleva una reducción en masa del $70 \%$, el volumen en que han de ser gestionados aún es considerable.

En la Comunidad Europea (CE) se producen anualmente del orden de 200 mega toneladas de estos residuos, cantidad que, teniendo en cuenta el aumento de población del $40 \%$ estimado para el año 2015, sobrepasará sustancialmente las medidas de control, almacenamiento, etc., actualmente vigentes en la CE para estos residuos.

Por tanto, se están llevando a cabo numerosas investigaciones sobre la búsqueda de aplicaciones potenciales de dichos residuos en el campo de la construcción: como áridos $(1,2)$, bloques de construcción (3), en carreteras $(4,5)$, etc. Entre los principales inconvenientes de estas aplicaciones se encuentran la expansión y su alto contenido en cloruros, por lo que los residuos tienen que ser tratados previamente a su incorporación en los materiales de construcción (6-10).

Debido a que estos residuos contienen, además de $\mathrm{Cl}$, elementos como $\mathrm{Ca}, \mathrm{Si}, \mathrm{Al}$, y $\mathrm{S}$, pueden ser empleados como materia prima para la fabricación de cementos especiales tipo sulfo-belíticos (11); de alinita (12), de fases con propiedades hidráulicas como el cloroaluminato cálcico (13) y reemplazando parcialmente las materias primas naturales del cemento Portland, después de su desalinización $(14,15)$.

Se presentan en este trabajo parte de los resultados de un proyecto de investigación en el que se ha estudiado el comportamiento frente a la temperatura (desde $800{ }^{\circ} \mathrm{C}$ hasta $1.200^{\circ} \mathrm{C}$ ) de los residuos generados en dos tipos de incineradoras españolas de residuos sólidos urbanos: la incineradora de Valdemingómez y la incineradora de Melilla, con el objetivo de explorar la viabilidad de su uso como materia prima para la obtención de fases cementantes. La principal diferencia de ambas incineradoras radica en el sistema de incineración: de lecho fluidizado en el caso de la incineradora de Valdemingómez y de horno de parrilla en la incineradora de Melilla. Esta diferente tecnología repercute en la composición química de los residuos correspondientes. Las fases obtenidas fueron caracterizadas por difracción de rayos $X$ y área superficial por el método $B E T-\mathrm{N}_{2}$.

\section{PROCEDIMIENTO EXPERIMENTAL}

Cantidades de $6 \mathrm{~g}$ de cada residuo se sometieron a un calentamiento controlado $\left(10^{\circ} \mathrm{C} / \mathrm{min}\right.$ hasta $600{ }^{\circ} \mathrm{C}$ y $5{ }^{\circ} \mathrm{C} / \mathrm{min}$ desde $600^{\circ} \mathrm{C}$ en adelante) a temperaturas de $800{ }^{\circ} \mathrm{C}, 900^{\circ} \mathrm{C}, 1.000^{\circ} \mathrm{C}, 1.100^{\circ} \mathrm{C}$ y $1.200^{\circ} \mathrm{C}$. Los análisis de difracción de rayos $\mathrm{X}$ se han realizado con un equipo Philips PW 1730 con cámara de grafito y una

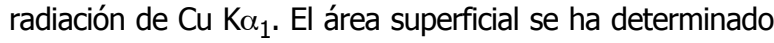

while incineration entails a $70 \%$ reduction of such waste by mass, it still leaves a considerable volume of residue to be managed.

The European Union (EU) generates on the order of 200 mega tonnes of such residue yearly. Taking into account the expected growth in world population, its production will exceed all of the control storage measurements of the EU., an amount which, given the region's estimated $40 \%$ rise in population by 2015 , will quickly outgrow the control and storage measures in place in the Union at this time.

Consequently, much research is underway to seek potential applications for incinerator residue in construction: in the form of aggregate (1, 2), masonry blocks (3), in roads $(4,5)$ and so on. The chief drawbacks in this connection include combustion product expandability and high chloride content, which necessitate ash/slag treatment prior to use in construction materials (6-10).

Inasmuch as the residue contains elements such as Ca, $\mathrm{Si}, \mathrm{Al}$ and $\mathrm{S}$ in addition to $\mathrm{Cl}$, it can be used as a prime material for manufacturing special sulpho-belite type cements (11), alinite (12), phases with hydraulic properties such as calcium chloroaluminate (13) and after desalination, to partially replace the natural prime materials in Portland cement $(14,15)$.

The present paper discusses part of the findings of a research project on the thermal behaviour (at temperatures from 800 to $1200^{\circ} \mathrm{C}$ ) of combustion products generated by two types of Spanish municipal solid waste incinerators, located at Valdemingómez, Madrid, and Melilla, to explore the viability of their use as a source of cementitious materials. The major difference between the two incinerators lies in the incineration technology involved: fluidized bed at Valdemingómez and grate furnace at Melilla. This difference in method affects the chemical composition of the respective residue. The phases obtained were characterized by $X$-ray diffraction and $B E T-N_{2}$ specific surface procedures.

\section{EXPERIMENTAL PROCEDURE}

Six grams of each type of combustion product were subjected to controlled heating $\left(10^{\circ} \mathrm{C} / \mathrm{min}\right.$ to $600^{\circ} \mathrm{C}$ and $5^{\circ} \mathrm{C} / \mathrm{min}$ from $600^{\circ} \mathrm{C}$ upward) to temperatures of 800 , $900,1,000,1,100$ and $1,200^{\circ} \mathrm{C}$. X-ray diffraction analyses were conducted with a Philips PW 1730 diffractometer fitted with a graphite monochromator, using $\mathrm{Cu} \mathrm{K \alpha _{1 }}$ radiation. The BET specific surface area was determined 
por el método BET con un equipo Micromeritics, modelo ASAP 2010, usando $\mathrm{N}_{2}-77 \mathrm{~K}$ gas. El procedimiento de lavado de los residuos se ha hecho según el trabajo de Abbas et al. (16).

- Relación agua desionizada/sólido = 2

- Tiempo 15 min con agitación

- Filtrar y secar a $100^{\circ} \mathrm{C}$

El filtrado se evaporó hasta sequedad y las sales se caracterizaron por difracción de rayos $\mathrm{X}$.

\section{RESULTADOS Y DISCUSIÓN}

\subsection{Caracterización de los residuos de incineración}

Los diferentes residuos han sido denominados con los siguientes códigos:

- R1: Incineradora de Valdemingómez. Ceniza de fondo de caldera procedente de los ciclones que recogen estos residuos a la salida del horno.

- R2: Incineradora de Valdemingómez. Ceniza volante procedente de los sistemas de depuración de gases.

- R3: Incineradora de Melilla. Ceniza volante procedente de los sistemas de depuración de gases.

- R4: Incineradora de Melilla. Escoria procedente del fondo del horno de la incineradora. with a Micromeritics ASAP 2010 analyzer, using $\mathrm{N}_{2}$ $77 K$ gas. The residue was washed as described by Abbas et al. (16).

- Deionized water/solid ratio $=2$

- Time: 15 min, stirred constantly

- Filtering and drying at $100^{\circ} \mathrm{C}$

The filtrate was evaporation dried and the salts were characterized by $X$-ray diffraction.

\section{RESULTS AND DISCUSSION}

\subsection{Residue characterization}

The different types of residue were coded as follows:

- R1: Valdemingómez incinerator. Bottom Ash from the bottom of the combustor, the return from the cyclones that collect this residue at the furnace outlet.

- R2: Valdemingómez incinerator. Fly ash from the gas purification systems.

- R3: Melilla incinerator. Fly ash from the gas purification systems.

- R4: Melilla incinerator. Slag from the bottom of the furnace.

Tabla 1 / Table 1

Composición química de los residuos (\% en peso)

Incinerator residue composition (\% by weight)

\begin{tabular}{|lllll|}
\hline & R1 & R2 & R3 & R4 \\
\hline R.I. / I.R. & 5.2 & 0.1 & 0.5 & 1.5 \\
\hline P.F. / L.O.I. & 4.6 & 17.6 & 16.6 & 7.5 \\
\hline $\mathrm{CaO}$ & 21.9 & 44.9 & 23.4 & 20.6 \\
\hline $\mathrm{SiO}_{2}$ & 34.1 & 11.4 & 12.8 & 46.2 \\
\hline $\mathrm{Al}_{2} \mathrm{O}_{3}$ & 19.3 & 11.3 & 10.0 & 9.3 \\
\hline $\mathrm{Fe}_{2} \mathrm{O}_{3}$ & 6.6 & 1.1 & 1.8 & 7.2 \\
\hline $\mathrm{MgO}$ & 2.6 & 1.9 & 3.1 & 1.9 \\
\hline $\mathrm{SO}_{3}$ & 3.3 & 3.9 & 7.6 & 1.1 \\
\hline $\mathrm{Na}_{2} \mathrm{O}$ & 0.8 & 2.0 & 9.4 & 5.8 \\
\hline $\mathrm{K}_{2} \mathrm{O}$ & 1.1 & 2.6 & 4.9 & 1.6 \\
\hline $\mathrm{Cl}-$ & 3.6 & 13.0 & 16.8 & 0.7 \\
\hline $\mathrm{Zn}(\mathrm{g} / \mathrm{kg})$ & 4.1 & 3.6 & 6.2 & 2.2 \\
\hline $\mathrm{Cd}(\mathrm{g} / \mathrm{kg})$ & 0.013 & 0.017 & 0 & 0.013 \\
\hline $\mathrm{Pb}(\mathrm{g} / \mathrm{kg})$ & 1.3 & 3.8 & 2.2 & 2.1 \\
\hline $\begin{array}{l}\text { Densidad }\left(\mathrm{g} / \mathrm{cm}^{3}\right) \\
\text { Density }\left(\mathrm{g} / \mathrm{cm}^{3}\right)\end{array}$ & 2.6 & 2.5 & 2.3 & 2.7 \\
\hline $\begin{array}{l}\text { Superficie }\left(\mathrm{m}_{2} / \mathrm{g}\right) \\
\text { Sp. surf. }\left(\mathrm{m}_{2} / \mathrm{g}\right)\end{array}$ & 0.22 & 0.73 & 0.56 & 0.39 \\
\hline $\mathrm{R.I} . \mathrm{Res} / \mathrm{nsol}$ & & & & \\
\hline
\end{tabular}

R.I. $=$ Residuo insoluble / I.R. $=$ Insoluble residue

P.F. = Pérdida al fuego $/$ L.O.I. $=$ loss on ignition 
Previamente a los ensayos realizados en este estudio, todos los residuos se desecaron en una estufa a la temperatura de $105 \pm 5^{\circ} \mathrm{C}$ durante 24 horas, con el fin de eliminar la humedad adquirida por los residuos durante el tiempo que permanecieron almacenados o durante su transporte. La composición química de los residuos se da en la Tabla 1.

Los componentes principales de todos los residuos son la cal $(\mathrm{CaO})$, la sílice $\left(\mathrm{SiO}_{2}\right)$ y la alúmina $\left(\mathrm{Al}_{2} \mathrm{O}_{3}\right)$, siendo también importante el contenido en óxido de hierro $\left(\mathrm{Fe}_{2} \mathrm{O}_{3}\right)$ en la ceniza de fondo y en las escorias ( $\mathrm{R} 1$ y $\left.\mathrm{R} 4\right)$, y el de cloruros $\left(\mathrm{Cl}^{-}\right)$y óxido de azufre (SO3) en las cenizas volantes (R2 y R3). El distinto origen de las cenizas y las escorias queda reflejado en su composición química. Así, las escorias de Melilla R4 presentan una cantidad mayor de sílice, debido a los materiales cerámicos y vidrios que quedan sin quemar y a la arena que se inyecta en la caldera en el caso de la escoria de lecho fluidizado de Valdemingómez (R1). Por otro lado, las cenizas proceden de los sistemas de depuración de gases, lo que explica el mayor contenido en $\mathrm{Cl}_{2}$ y $\mathrm{SO}_{3}$, ya que éstos son gases producidos por la combustión que quedan retenidos en los filtros en forma de cloruros y sulfatos. Las cenizas de horno de parrilla (R3) presentan un contenido en álcalis $\left(\mathrm{Na}_{2} \mathrm{O}\right.$ y $\left.\mathrm{K}_{2} \mathrm{O}\right)$ netamente superior a los otros residuos, estos álcalis se encuentran formando cloruros cristalinos, concretamente cloruro sódico y cloruro potásico.
Before testing, the various types of residue were dried in a stove for 24 hours at a temperature of $105 \pm 5^{\circ} \mathrm{C}$ to eliminate the moisture acquired during storage or shipping. The chemical composition of the residue is given in Table 1.

The main components of all incinerator residue were lime $(\mathrm{CaO})$, silica $\left(\mathrm{SiO}_{2}\right)$ and alumina $\left(\mathrm{Al}_{2} \mathrm{O}_{3}\right)$, while substantial amounts of iron oxide $\left(\mathrm{Fe}_{2} \mathrm{O}_{3}\right)$ were found in the bottom ash and slag (R1 and R4) and the fly ash (R2 and R3) contained chlorides ( $\mathrm{Cl}$ ) and sulphur trioxide $\left(\mathrm{SO}_{3}\right)$. The chemical differences between the ash and slag are the result of their different origin. The slag contained more silica, due in the case of the Melilla product (R4) to the presence of unburnt ceramic material and glass, and in the Valdemingómez residue ( $R 1)$ to the sand fed into fluidized bed combustor. The ash, in turn, was generated in the gas purification systems, which would explain its higher $\mathrm{Cl}_{2}$ and $\mathrm{SO}_{3}$ content, for combustion flue gases are retained in the filters in the form of chlorides and sulphates. Ash from the grate furnace (R3) had a visibly higher alkali content $\left(\mathrm{Na}_{2} \mathrm{O}\right.$ and $\left.\mathrm{K}_{2} \mathrm{O}\right)$ than the other types of residue, found in the form of crystalline sodium and potassium chloride.

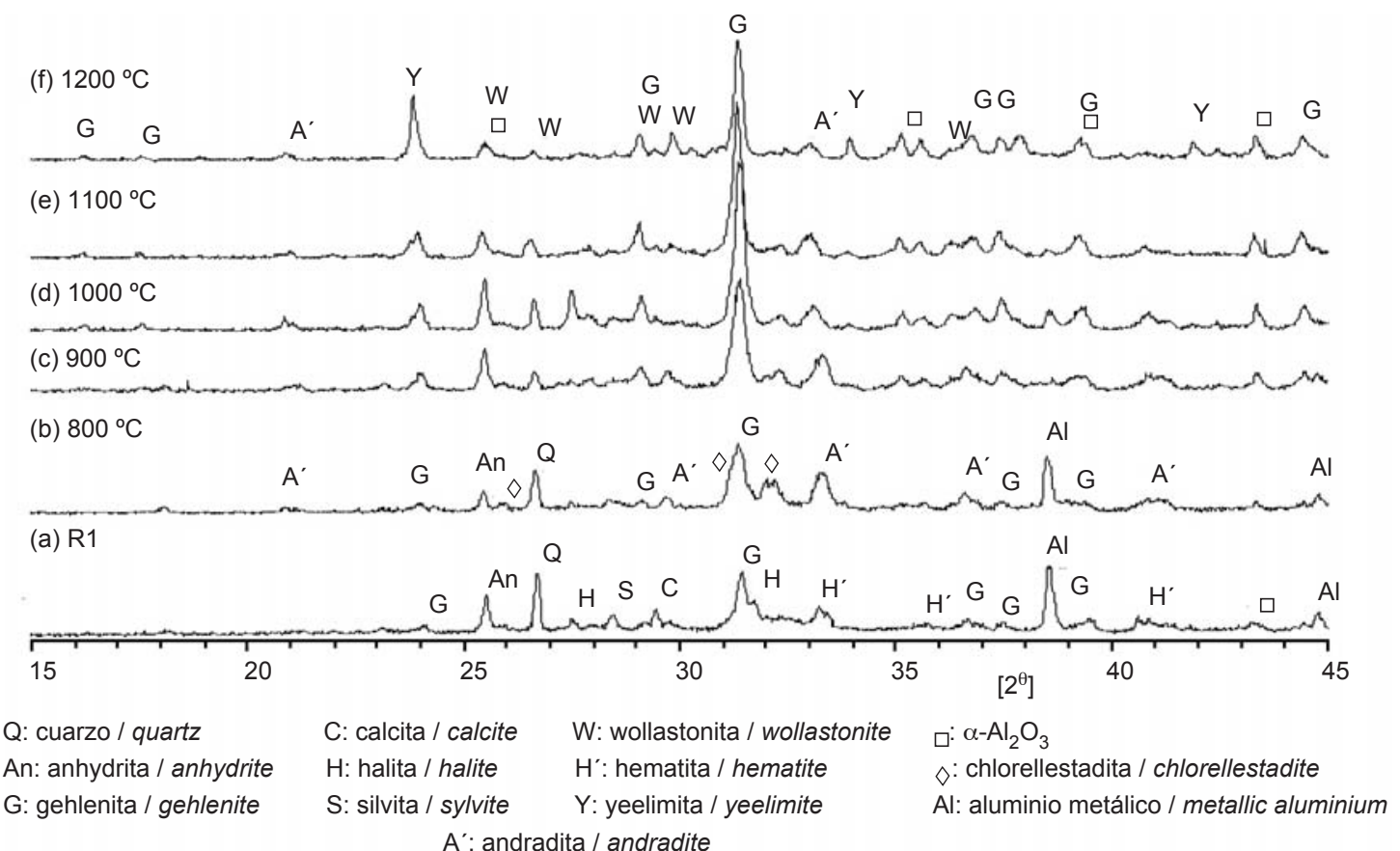

Figura 1. Evolución de los difractogramas de rayos $X$ del residuo $\mathrm{R} 1$ con la temperatura. Figure 1 . Variation in residue $R 1 X$-ray diffractograms with temperature. 


\subsection{Evolución de los residuos con el calentamiento}

Ceniza de fondo de Lecho Fluidizado (R1) (Figura 1): como se puede ver en la Figura 1 (a), la ceniza está formada principalmente por cuarzo $\left(\mathrm{SiO}_{2}\right)$. Esta cantidad de cuarzo tan alta proviene de la arena de sílice que se añade en la cámara de combustión; también tiene una cantidad importante de aluminio metálico, anhidrita $\left(\mathrm{CaSO}_{4}\right)$ que proviene de la cal o dolomita que dentro del lecho reacciona con los gases ácidos $\left(\mathrm{SO}_{3}\right)$, y de cloruros cristalinos como la silvita (CIK), la halita ( $\mathrm{CINa})$, compuestos que provienen de la sal común de los alimentos. Otros compuestos que se pueden observar en la composición cristalográfica son hematita $\left(\mathrm{Fe}_{2} \mathrm{O}_{3}\right)$, calcita $\left(\mathrm{CaCO}_{3}\right)$ y gehlenita $\left(\mathrm{Ca}_{2} \mathrm{Al}_{2} \mathrm{SiO}_{7}\right)$.

A $800^{\circ} \mathrm{C}$ (Figura 1 (b)) desaparecen las fases cloradas silvita y halita y la anhidrita y cuarzo disminuyen considerablemente, como consecuencia se forma la fase chlorellestadita $\left(\mathrm{Ca}_{10}\left(\mathrm{SiO}_{4}\right)_{3}\left(\mathrm{SO}_{4}\right)_{3} \mathrm{Cl}_{2}\right)$, de la familia de las alinitas. $\mathrm{La}$ hematita se transforma en andradita $\left(\mathrm{Ca}_{3} \mathrm{Fe}_{2}\left(\mathrm{SiO}_{3}\right)_{3}\right)$. El aluminio metálico desaparece a los $900{ }^{\circ} \mathrm{C}$ (Figura 1 (c)) dando lugar a la variedad a del $\mathrm{Al}_{2} \mathrm{O}_{3}$ (corundón). La intensidad de las reflexiones de la gelenita $\left(C_{2} A S\right)$ aumenta considerablemente a partir de esta temperatura; además, la fase wollastonita $\left(\mathrm{CaSiO}_{3}\right)$ comienza a formarse, probablemente a expensas del cuarzo. La fase yelimita $\left(\mathrm{Ca}_{4} \mathrm{Al}_{6} \mathrm{O}_{12}\left(\mathrm{SO}_{4}\right)\right)$ se detecta a $1.100{ }^{\circ} \mathrm{C}$ (Figura 1(e)) aumentando considerablemente a $1.200{ }^{\circ} \mathrm{C}$ donde la anhidrita desaparece para dar lugar a dicha fase. De todos los compuestos identificados por DRX, la wollastonita y yelimita son fases cementantes con carácter hidráulico, concretamente la yeelimita es la fase principal de los cementos denominados de sulfoaluminato cálcico (SFC); sin embargo, su bajo contenido calculado a partir de la cantidad de $\mathrm{SO}_{3}$ presente en el residuo 3,3\% (véase Tabla 1 ) sugiere que durante la hidratación no se va a producir el endurecimiento, como veremos más adelante.

\subsection{Variation in residue with heating}

Fluidized bed bottom ash (R1) (Figure 1): as Figure 1 (a) shows, this slag consisted primarily of quartz $\left(\mathrm{SiO}_{2}\right)$. The source was the silica sand fed into the combustion chamber; this cottomash also contained substantial amounts of metallic aluminium, anhydrite $\left(\mathrm{CaSO}_{4}\right)$ gene-rated by the lime or dolomite that captures acid gases $\left(\mathrm{SO}_{3}\right)$ inside the incinerator, and crystalline chlorides such as sylvite (CIK), and halite (CINa), i.e., whose origin is the common salt found in food. Other compounds detected in the crystallographic composition included hematite $\left(\mathrm{Fe}_{2} \mathrm{O}_{3}\right)$, calcite $\left(\mathrm{CaCO}_{3}\right)$ and gehlenite $\left(\mathrm{Ca}_{2} \mathrm{Al}_{2} \mathrm{SiO}_{7}\right)$.

The chlorinated phases sylvite and halite disappeared at $800{ }^{\circ} \mathrm{C}$ (Figure 1 (b)), and the amounts of anhydrite and quartz declined substantially, with the concomitant formation of chlorellestadite $\left(\mathrm{Ca}_{10}\left(\mathrm{SiO}_{4}\right)_{3}\left(\mathrm{SO}_{4}\right)_{3} \mathrm{Cl}_{2}\right)$, a member of the alinite family. The hematite, in turn, was converted into andradite $\left(\mathrm{Ca}_{3} \mathrm{Fe}_{2}\left(\mathrm{SiO}_{4}\right)_{3}\right)$. The metallic aluminium disappeared at $900^{\circ} \mathrm{C}$ (Figure 1 (c)), giving rise to the a variety of $\mathrm{Al}_{2} \mathrm{O}_{3}$ (corundum). The intensity of the gehlenite $\left(C_{2} A S\right)$ signals grew substantially from this temperature upward, and wollastonite $\left(\mathrm{CaSiO}_{3}\right)$ began to form, probably at the expense of the quartz. Yeelimite $\left(\mathrm{Ca}_{4} \mathrm{Al}_{6} \mathrm{O}_{12}(\mathrm{SO} 4)\right)$ was detected at $1,100{ }^{\circ} \mathrm{C}$ (Figure 1(e)) and its content increased considerably at $1,200{ }^{\circ} \mathrm{C}$, replacing the anhydrite. Of all the compounds identified by $X R D$, wollastonite and yeelimite were the only hydraulic cementitious phases; and in fact yeelimite is the main phase in so-called calcium sulphoaluminate (CSA) cements; the low content of this mineral, however, computed from the amount of $\mathrm{SO}_{3}$ present in the residue (3.3\% - see Table 1), suggested that it would not harden with hydration, as discussed below.

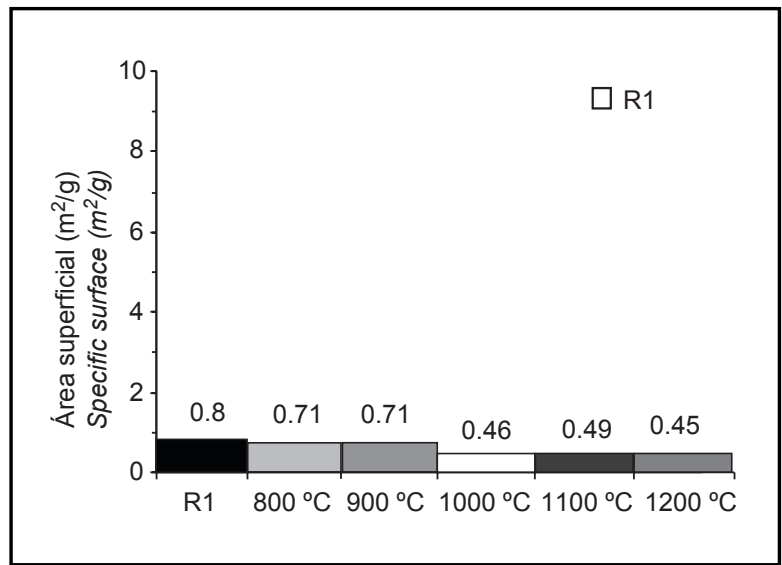

Figura 2. Evolución del área superficial del residuo R1 con la temperatura.

Figure 2. Variation in residue $R 1$ specific surface with temperature. 




Figura 3. Evolución del difractograma de rayos $X$ del residuo R2 con la temperatura.

Figure 3. Variation in residue $R 2 X$-ray diffractograms with temperature.

La evolución del área superficial $B E T-\mathrm{N}_{2}$ del residuo $\mathrm{R} 1$ durante el calentamiento se presenta en la Figura 2. El área superficial es indicativo de la finura de la muestra y, por tanto, de su reactividad potencial: cuando mayor sea el área superficial, mayor será su reactividad. Como se puede ver en la Figura 2, el área superficial del residuo disminuye con la temperatura de calentamiento hasta alcanzar los $1.000^{\circ} \mathrm{C}$, prácticamente la mitad de su valor.

Ceniza de lecho fluidizado (R2) (Figura 3): como se puede apreciar en la Figura 3 (a), este residuo está formado principalmente por cloruros cristalinos como silvita $(\mathrm{KCl})$, halita $(\mathrm{NaCl})$ y la hidroxisal de calcio $\left(\mathrm{CaCl}_{2} \cdot \mathrm{Ca}(\mathrm{OH})_{2} \cdot \mathrm{H}_{2} \mathrm{O}\right)$,
Figure 2 shows the variation in the BET- $N_{2}$ specific surface of residue $R 1$ during the heating process. The specific surface area is indicative of sample fineness and therefore of its potential reactivity: the greater the specific surface, the higher the reactivity. The specific surface of this residue declined with heating temperature, tumbling by almost $50 \%$ of the initial value at $1,000{ }^{\circ} \mathrm{C}$, as can be inferred from the figure.

Fluidized bed ash (R2) (Figure 3): as Figure 3 (a) shows, this residue consisted primarily in crystalline chlorides such as sylvite $(\mathrm{KCl})$, halite $(\mathrm{NaCl})$ and calcium hydroxysalt $\left(\mathrm{CaCl}_{2} \cdot \mathrm{Ca}(\mathrm{OH})_{2} \cdot \mathrm{H}_{2} \mathrm{O}\right)$, with a substantial amount of

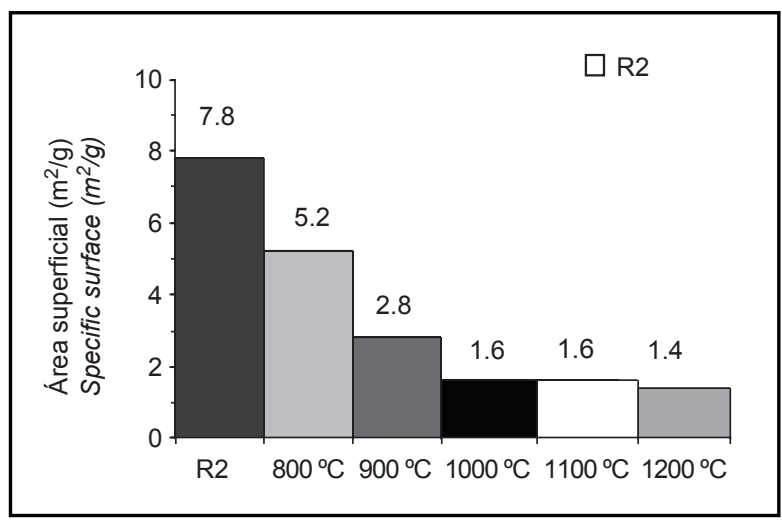

Figura 4. Evolución del área superficial del residuo R2 con la temperatura. Figure 4. Variation in residue $R 2$ specific with temperature. 
también tiene una cantidad importante de anhydrita $\left(\mathrm{CaSO}_{4}\right)$. Como ocurre en la ceniza de horno de parrilla (R3), la existencia de la hidroxisal y del sulfato cálcico se debe a que las cenizas provienen de los filtros de depuración de gases, donde se añade una lechada de cal para neutralizar los gases ácidos, el cloro contenido en estos gases $(\mathrm{HCl})$ precipita en los filtros en forma de cloruros cristalinos y los gases de $\mathrm{SO}_{3}$ en forma sulfatos. En su composición mineralógica también se puede observar, aunque en menor medida, calcita $\left(\mathrm{CaCO}_{3}\right)$, portlandita $\left(\mathrm{Ca}(\mathrm{OH})_{2}\right)$ y gehlenita $\left(\mathrm{Ca}_{2} \mathrm{Al}_{2} \mathrm{SiO}_{7}\right.$ o $\left.\mathrm{C}_{2} \mathrm{AS}\right)$.

A $800{ }^{\circ} \mathrm{C}$ (Figura 3 (b)) se forman las fases alinita $\left(\mathrm{Ca}_{10}\right.$ $\left.\mathrm{Mg0},{ }_{18}\left(\mathrm{SiO}_{4}\right)_{3,4}\left(\mathrm{AlO}_{4}\right)_{0,6} \mathrm{O}_{2} \mathrm{Cl}\right)$, chlorellestadita $\left(\mathrm{Ca}_{10}\left(\mathrm{SiO}_{4}\right)_{3}\right.$ $\left.\left(\mathrm{SO}_{4}\right)_{3} \mathrm{Cl}_{2}\right)$ de la familia de las alinitas y mayenita $\left(\mathrm{C}_{12} \mathrm{~A}_{7}\right)$. La silvita $(\mathrm{KCl})$ y la halita $(\mathrm{NaCl})$ desaparecen a $1.200{ }^{\circ} \mathrm{C}$ (Figura 3 (f)). Al contrario del residuo R1, durante su hidratación se endurecieron, no produciéndose fenómenos de expansión. A temperaturas superiores a $1.200{ }^{\circ} \mathrm{C}$ no se producen cambios en las fases obtenidas.

La mayor reactividad de estas cenizas se refleja también en su área superficial (Figura 4), cuyo valor es considerablemente superior al residuo $\mathrm{R} 1$, por esto estas cenizas también se denominan cenizas volantes por su pequeño tamaño. Al aumentar la temperatura de calentamiento, el área superficial disminuye debido a las anhydrite $\left(\mathrm{CaSO}_{4}\right)$. As in the grate furnace ash (R3), the presence of hydroxysalt and calcium sulphate was due to the presence of lime grout in the gas purification filters, used to neutralize acid gases. This prompted chlorine precipitation out of the flue gases $(\mathrm{HCl})$ in the form of crystalline chlorides and $\mathrm{SO}_{3}$ gases in the form of sulphates. Calcite $\left(\mathrm{CaCO}_{3}\right)$, portlandite $\left(\mathrm{Ca}(\mathrm{OH})_{2}\right)$ and gehlenite $\left(\mathrm{Ca}_{2} \mathrm{Al}_{2} \mathrm{SiO}_{7}\right.$ or $\left.\mathrm{C}_{2} \mathrm{AS}\right)$ can also be observed in the mineralogical composition of this ash, albeit in smaller quantities.

Alinite $\left(\mathrm{Ca}_{10} \mathrm{Mg}_{0.8}\left(\mathrm{SiO}_{4}\right)_{3.4}\left(\mathrm{AlO}_{4}\right)_{0.6} \mathrm{O}_{2} \mathrm{Cl}\right)$ and chlorellestadite $\left(\mathrm{Ca}_{10}(\mathrm{SiO} 4)_{3}\left(\mathrm{SO}_{4}\right)_{3} \mathrm{Cl}_{2}\right)$, both of the alinite family, as well as mayenite $\left(C_{12} A_{7}\right)$, formed at $8000^{\circ} \mathrm{C}$ (Figure $3(\mathrm{~b})$ ). Sylvite $(\mathrm{KCl})$ and halite $(\mathrm{NaCl})$ disappeared at 1,200 ${ }^{\circ} \mathrm{C}$ (Figure $3(f)$ ). Unlike residue $R 1$, these phases hardened during hydration, and no expansion was recorded (see Table 6). No changes were observed in any of the phases at temperatures of over $1,200^{\circ} \mathrm{C}$.

Most of the reactivity of this ash was likewise reflected in its specific surface (Figure 4), which was substantially higher than in residue $R 1$; indeed, in light of the small size of the particles, it is also referred to as a fly ash. As the temperature rose, the specific surface area declined due to phase transformation and particle sintering. The

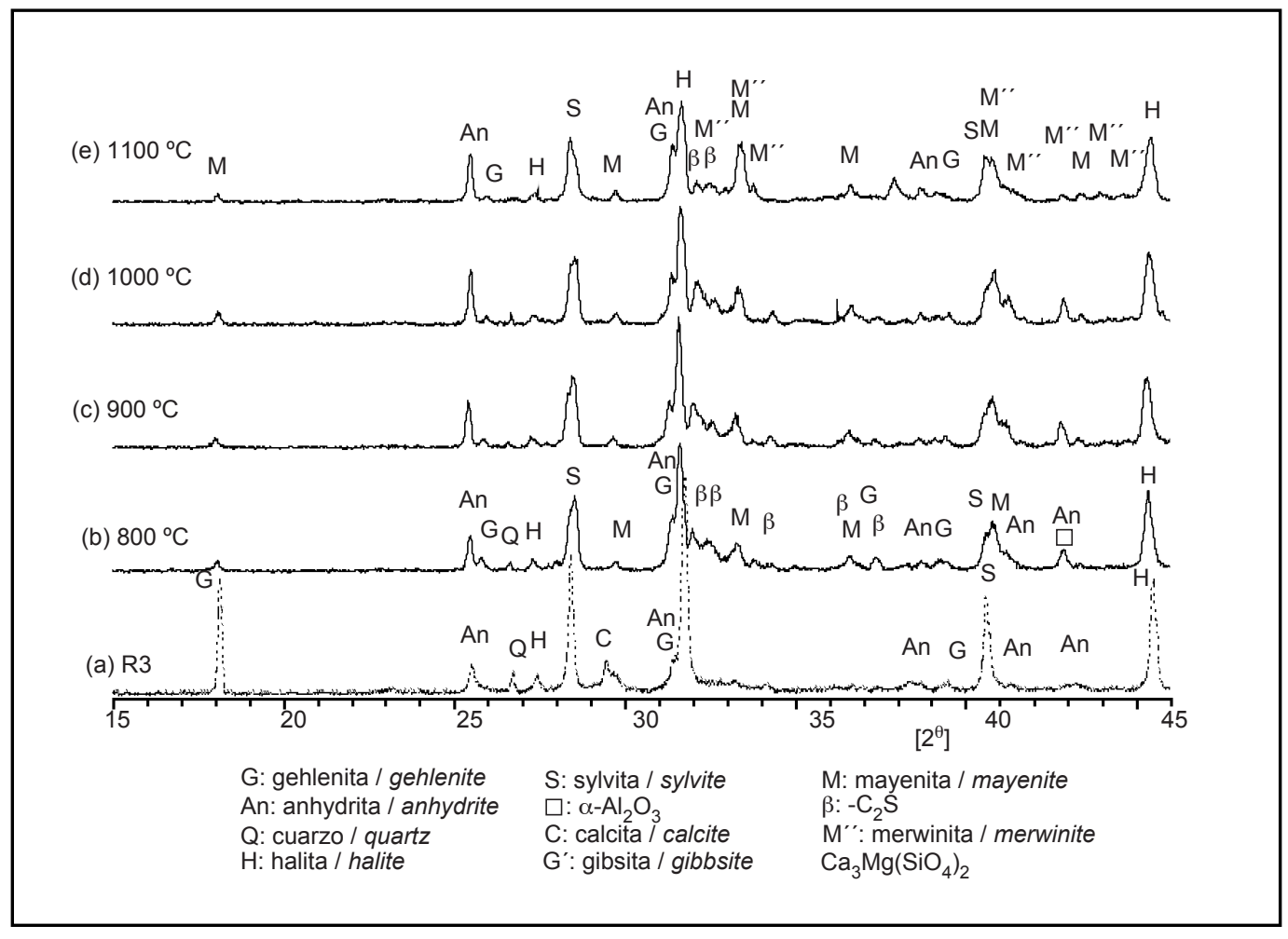

Figura 5. Evolución del Difractograma de Rayos X del Residuo R3 con la Temperatura. Figure 5. Variation in residue $R 3 X$-ray diffractograms with temperature. 


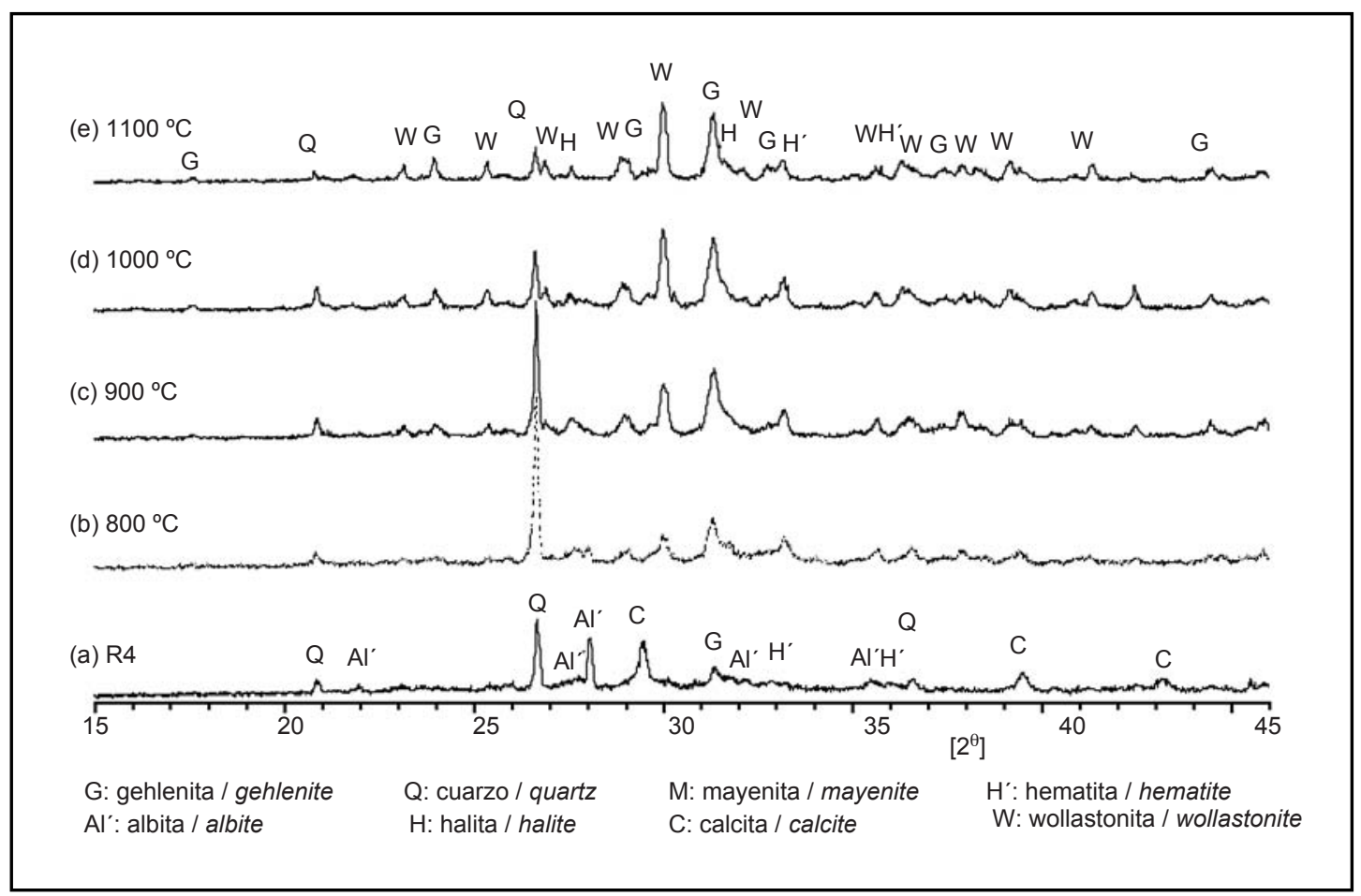

Figura 6. Evolución del difractograma de rayos $X$ del residuo $\mathrm{R} 4$ con la temperatura. Figure 6. Variation in residue $R 4 X$-ray diffractograms with temperature.

transformaciones de fases y a la sinterización de las partículas. A $1.000{ }^{\circ} \mathrm{C}$ el área superficial es $1,6 \mathrm{~m}^{2} / \mathrm{g}$, permaneciendo casi sin alteraciones hasta $1.200{ }^{\circ} \mathrm{C}$.

Ceniza de horno de parrilla (R3) (Figura 5): este residuo contiene las fases halita $(\mathrm{NaCl})$ y silvita $(\mathrm{KCl})$ en gran proporción. Debido a esto, el calentamiento sólo se pudo realizar hasta la temperatura de $1.100{ }^{\circ} \mathrm{C}$, pues a mayores temperaturas se producía la volatilización de la halita y silvita, creando problemas de corrosión en el horno. Durante el calentamiento hasta $1.100{ }^{\circ} \mathrm{C}$ el principal cambio es la formación de la fase merwinita $\left(\mathrm{Ca}_{3} \mathrm{Mg}\left(\mathrm{SiO}_{4}\right)_{2}\right.$ y un aumento de la gelenita $\left(\mathrm{C}_{2} \mathrm{AS}\right)$ y anhidrita; a bajas temperaturas se forma el $\beta-\mathrm{C}_{2} S$ (Figura $5(\mathrm{~b})$ ) que disminuye a $1.100{ }^{\circ} \mathrm{C}$ (Figura $5(\mathrm{e})$ ). La mayenita $\left(\mathrm{C}_{12} \mathrm{~A}_{7}\right)$ se forma a $800^{\circ} \mathrm{C}$ y permanece constante con la temperatura.

Escoria de horno de parrilla (R4) (Figura 6): la nueva fase formada durante el calentamiento es la wollastonita $\left(\mathrm{CaSiO}_{3}\right)$, que comienza a aparecer a los $800{ }^{\circ} \mathrm{C}$ specific surface value of $1.6 \mathrm{~m}^{2} / \mathrm{g}$ recorded at $1,000{ }^{\circ} \mathrm{C}$ remained essentially constant up to $1,200^{\circ} \mathrm{C}$.

Grate furnace ash (R3) (Figure 5): this residue contained large proportions of halite $(\mathrm{NaCl})$ and sylvite $(\mathrm{KCl})$. As a result, it could not be heated to temperatures higher than $1,100{ }^{\circ} \mathrm{C}$, for upward of that value the halite and sylvite volatized, causing oven corrosion. During heating to $1,100{ }^{\circ} \mathrm{C}$ the major changes were the formation of merwinite $\left(\mathrm{Ca}_{3} \mathrm{Mg}\left(\mathrm{SiO}_{4}\right)_{2}\right.$ and increases in gehlenite $\left(C_{2} A S\right)$ and anhydrite; $\beta-C_{2} S$ formed at lower temperatures (Figure $5(b))$ but its content declined at $1,100{ }^{\circ} \mathrm{C}$ (Figure $5(e)$ ). Mayenite $\left(C_{12} A_{7}\right)$ formed at $800^{\circ} \mathrm{C}$ and remained constant throughout.

Grate furnace slag (R4) (Figure 6): the new phase formed during heating, wollastonite, (CaSiO3), began to appear at $800{ }^{\circ} \mathrm{C}$ (Figure 6 (b)) and the intensity of its

Tabla 2 / Table 2

Cloruros analizados en los residuos antes y después del lavado (\% en peso de muestra seca) Chloride values in residue before and after washing (\% by dry weight of sample)

\begin{tabular}{|cccc|}
\hline & $\begin{array}{c}\text { Sin lavar } \\
\text { Unwashed }\end{array}$ & $\begin{array}{c}\text { Lavados } \\
\text { Washed }\end{array}$ & $\begin{array}{c}\text { Extraídos } \\
\text { Extracted }\end{array}$ \\
\hline R2 & 13.0 & 8.0 & $38.5 \%$ \\
\hline R3 & 16.8 & 3.8 & $77.4 \%$ \\
\hline
\end{tabular}


(Figura 6 (b)), aumentando la intensidad de sus picos progresivamente con la temperatura. La fase gelenita también aumenta con la temperatura.

\subsection{Lavado de los residuos}

En la Tabla 2 se dan los cloruros analizados en los residuos antes y después del lavado. En la Figura 7 se puede observar las diferencias que ha provocado el lavado en los residuos y las sales de los concentrados de evaporador. En el caso de los concentrados de evaporador, los compuestos cristalinos corresponden a la halita $(\mathrm{NaCl})$ y silvita $(\mathrm{KCl})$, presentes en mayor proporción en peaks rose with temperature. Gehlenite content also grew with rising temperature.

\subsection{Residue washing}

The chloride values before and after washing are given in Table 2. Figure 7 shows the salts in the evaporator concentrates and the differences in the residue occasioned by washing. In the evaporator concentrates, the crystalline compounds found were halite $(\mathrm{NaCl})$ and sylvite $(K C l)$, present in higher proportions in the ash $\mathrm{R} 3$ concentrate. The ash $R 2$ concentrate contained, in addition,

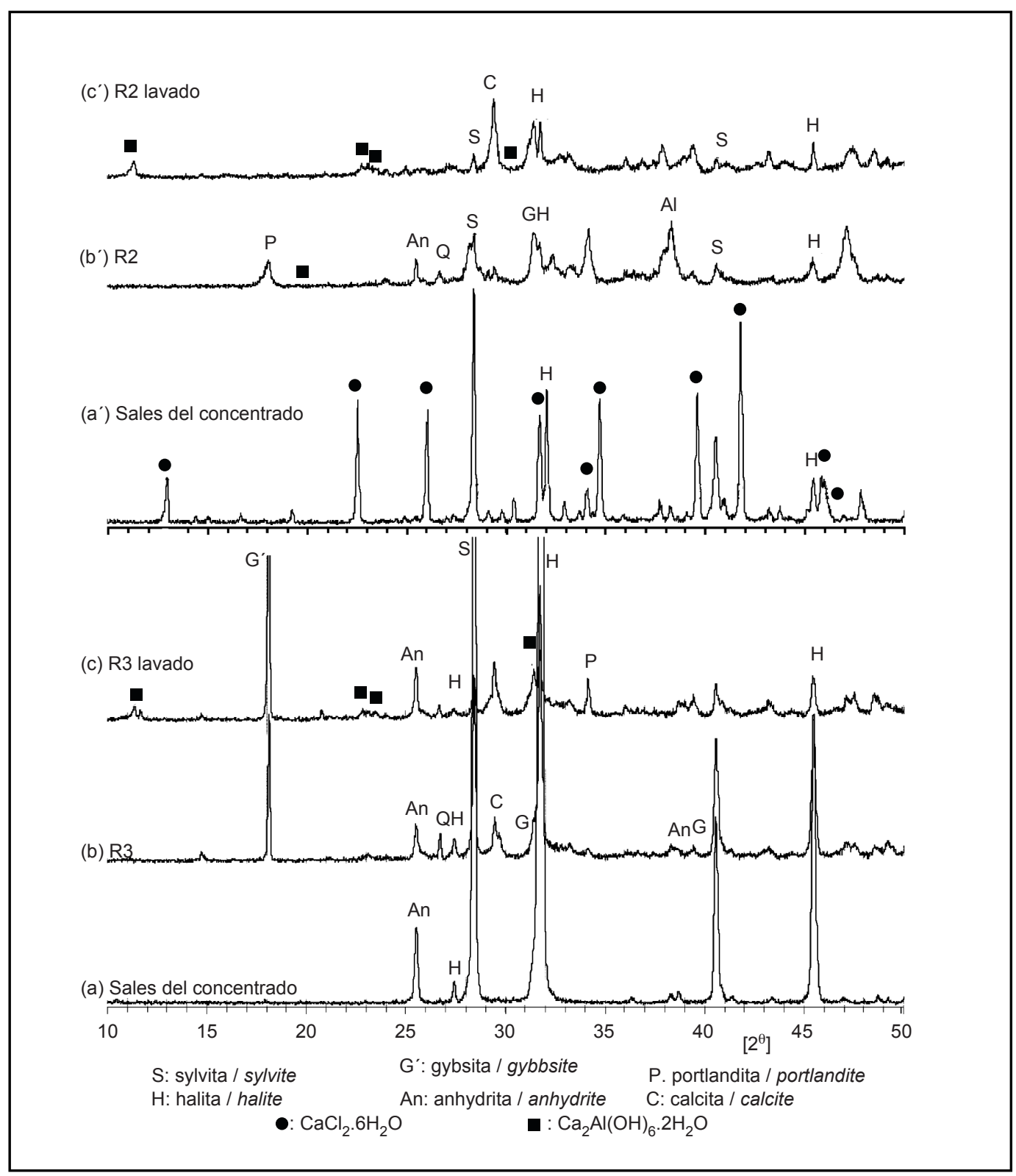

Figura 7. Análisis por difracción de rayos X. Influencia del lavado en las cenizas R2 y R3 y sales de los concentrados de evaporador. Figure 7. X-ray diffaction. Evaporator concentrate salts and effect of washing on R2 and R3. 

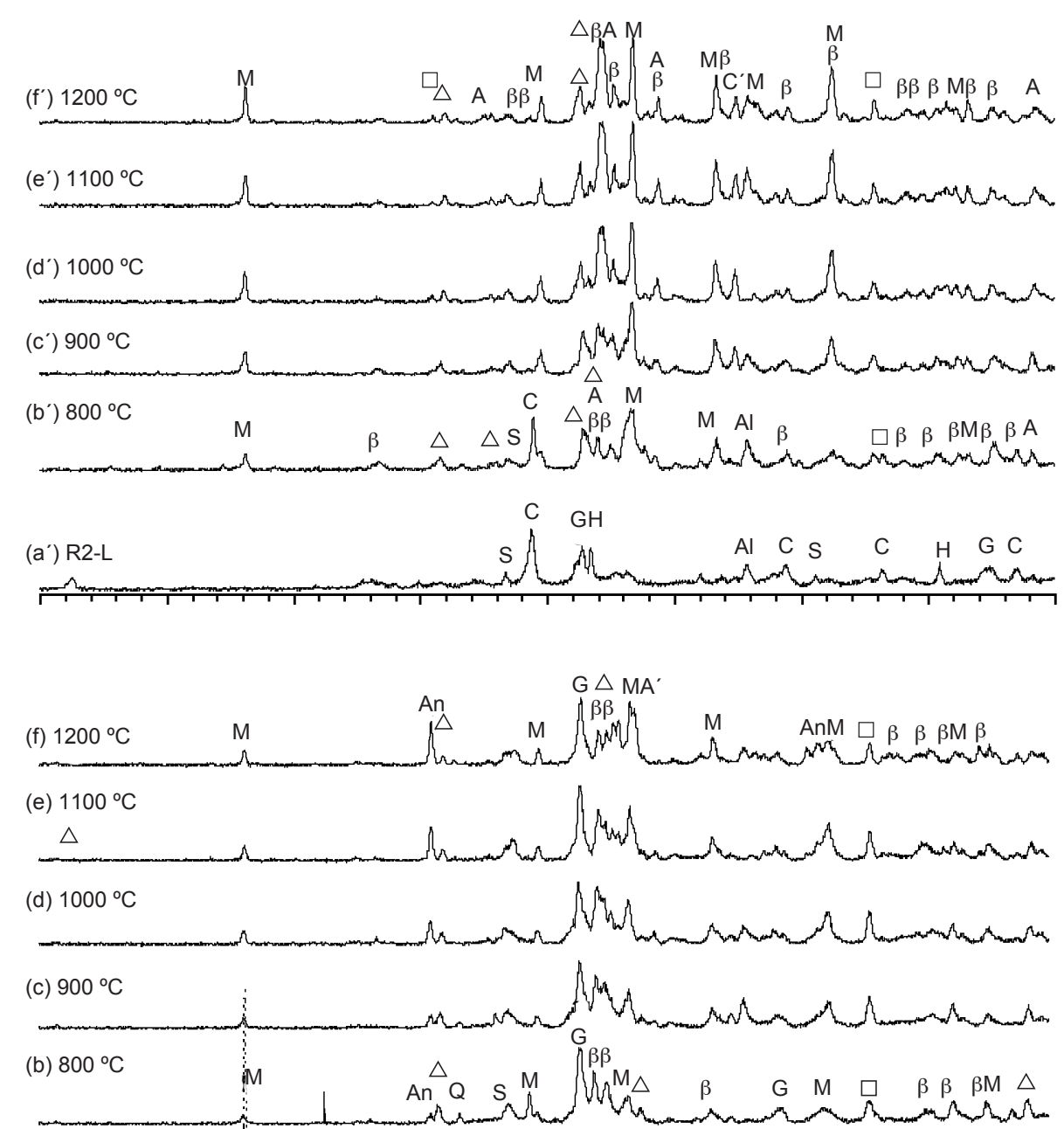

(a) R3-L

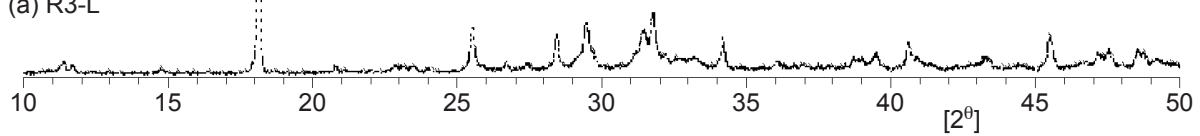

$\begin{array}{llll}\text { M: mayenita / mayenite } & \text { An: anhydrita / anhydrite } & \text { G: gehlenita / gehlenite } & \text { A: alinita / alinite } \\ \beta: C_{2} S & \triangle \text { : clorellestadita / chlorellestadite } & \mathrm{G} \text { : gibsita / gibbsite } & \square: \alpha-\mathrm{Al}_{2} \mathrm{O}_{3} \\ \text { Q: cuarzo / quartz } & \mathrm{S}: \text { sylvita / sylvite } & \mathrm{H}: \text { halita / halite } & \mathrm{C}: \text { calcita / calcite }\end{array}$

Figura 8. Análisis por difracción de rayos X. Influencia del calentamiento de las cenizas R2 y R3 y lavadas. Figure 8. X-ray diffaction. Influence of heating on washed $R 2$ and $R 3$.

el concentrado de la ceniza R3. En el concentrado de la ceniza R2, además se extrajeron diferentes hidratos del $\mathrm{CaCl}_{2}: \mathrm{CaCl}_{2 \cdot 6} \mathrm{H}_{2} \mathrm{O}$ y $\mathrm{CaCl}_{2} \cdot 4 \mathrm{H}_{2} \mathrm{O}$. En ambas cenizas lavadas se forma $\mathrm{Ca}_{2} \mathrm{Al}(\mathrm{OH})_{6} \mathrm{Cl} .2 \mathrm{H} 2 \mathrm{O}$.

\subsection{Evolución de los residuos lavados con el calentamiento}

Se repitió el proceso de calentamiento en el horno con los residuos lavados con el fin de ver la influencia del lavado en las fases obtenidas, cuyos resultados se muestran en la Figura 8. En el caso del residuo R2, la halita $(\mathrm{NaCl})$ desaparece a los $800^{\circ} \mathrm{C}$ y la máxima intensidad
$\mathrm{CaCl}_{2}$ hydrates: $\mathrm{CaCl}_{2} \cdot 6 \mathrm{H}_{2} \mathrm{O}$ and $\mathrm{CaCl}_{2} \cdot 4 \mathrm{H}_{2} \mathrm{O}$. The hydrate $\mathrm{Ca}_{2} \mathrm{Al}(\mathrm{OH})_{6} \mathrm{Cl} .2 \mathrm{H}_{2} \mathrm{O}$ formed in both types of ash.

\subsection{Variation in the washed residue after heating}

The washed residue was also heated to determine the effect of washing on the phases obtained; the results are shown in Figure 8 . In residue $R 2$, halite disappeared at $800{ }^{\circ} \mathrm{C}$ and the maximum alinite intensity was recorded at $1,100{ }^{\circ} \mathrm{C}$. Halite also disappeared at 
de la alinita se obtiene a los $1.100^{\circ} \mathrm{C}$. En el caso del residuo R3, la halita también desaparece a los $800{ }^{\circ} \mathrm{C}$; la mayenita $\left(\mathrm{C}_{12} \mathrm{~A}_{7}\right)$ se forma en mayor grado si se compara con la muestra sin lavar; como fases nuevas se forma la larnita $\left(\beta-\mathrm{C}_{2} \mathrm{~S}\right)$, andradita $\left(\mathrm{Ca}_{3} \mathrm{Fe}_{2}\left(\mathrm{SiO}_{4}\right)_{3}\right)$ y chlorellestadita $\left(\mathrm{Ca}_{10}\left(\mathrm{SiO}_{4}\right)_{3}\left(\mathrm{SO}_{4}\right)_{3} \mathrm{Cl}_{2}\right)$.

\section{AGRADECIMIENTOS}

Los autores agradecen a la Comunidad de Madrid (CAM) y a la CICYT la financiación de los proyectos (07M/ 0052/1999) (MAT95-0054) (BQU2000-1357) y (PB980516).
$800{ }^{\circ} \mathrm{C}$ in residue $\mathrm{R} 3$; more mayenite $\left(C_{12} A_{7}\right)$ formed than in the unwashed residue; and new phases appeared, namely larnite $\left(\beta-\mathrm{C}_{2} \mathrm{~S}\right)$, andradite $\left(\mathrm{Ca}_{3} \mathrm{Fe}_{2}\left(\mathrm{SiO}_{4}\right)_{3}\right)$ and chlorellestadite $\left.\left.\left(\mathrm{Ca}_{10}\left(\mathrm{SiO}_{4}\right)_{3}\right) \mathrm{SO}_{4}\right)_{3} \mathrm{Cl}_{2}\right)$.

\section{BIBLIOGRAFÍA / BIBLIOGRAPHY}

(1) Wainwright P. J. y Robery, P.: "Production and Properties of Sintered Incinerator Residues as Aggregate for Concrete", Waste Materials in Construction, J.J.J.R. Goumans, H. A. Van der Sloot and Th.G. Aalbers (editors), Elsevier Science Publisher, 1991, pp. 425-432.

(2) Pera, J., Coutaz, L., Ambroise, J. y Chababbet, M.: "Use of Incinerator Bottom Ash in Concrete", Cem. Concr. Res, vol. 27(1997), no 1 , pp. 1-5.

(3) Ali, M.T. y Chang, W. F.: "Strength Properties of Cement Stabilized Municipal Solid Waste Incinerator Ash masonry Bricks", ACI Materials Journal, vol. 91, no 3 (1994), pp. 256-263.

(4) Gress, D. L., Zhang, X., Tarr, S., Pazienza, I. y Eighmy, T. T.: "Municipal Solid Waste Combustion Ash as an Aggregate Substitute in Asphaltic Concrete", Waste Materials in Construction, J.J.J.R. Goumans, H. A. Van der Sloot and Th.G. Aalbers (editors), Elsevier Science Publisher, pp. 161-175, 1991.

(5) Nonneman, D. J., Hansen, F. A. y Coppens, M. H. M.: "The Use of Incinerator Slag in Asphalt for Road Construction", Waste Materials in Construction, J.J.J.R. Goumans, H. A. Van der Sloot and Th.G. Aalbers (editors). Elsevier Science Publisher, pp. 569-578 (1991). (6) Crignon, C., Pecqueur, G. y García Díaz, E.: "Study of Cement-Treated MSWI Bottom Ash Expansion", Proc. of International Conference on Waste Stabilisation and Environment, Ed.: Société Alpine de Publications, 1999, pp. 64-68.

(7) Alkemade, M. M. C., Eymael, M. M. Th., Mulder, E. y De Wijs, W.: "How to Prevent Expansion of MSWI Bottom Ash in Road Construction" Environmental Aspects of Construction with Waste Materials, J.J.J.M. Goumans, H. A. Van der Sloot and ThG. Aalbers (editors), 1994, pp. 863-876. (8) Barbery, O. y Ghodsi, A.: "Trapping of Chloride, Sulfate and Heavy Metals", Proc. of the International Symposium on Sustainable Construction: Use of Incinerator Ash. Ed. by Ravindra K. Dhir, Tom D. Dyer and Kevin A. Paine, Publishers Thomas Telford, Londres, 2000, pp. 173-183. (9) Nzihou, A. y Sharrock, P.: "Extraction of Chloride from Fly Ash and Stabilisation of the Residues by a Hydroxylapatite Sol-Gel Process", Proc. of International Conference on Waste Stabilisation and Environment, Ed. Société Alpine de Publications, 1999, pp. 30-35.

(10) Guerrero, A., Fernández, E., Macías, A. y Goñi, S.: "Hydrothermal Treatment of Fly Ash from Municipal Solid Waste Incineration", Proceedings of Waste Materials in Construction: Science and Engineering of Recycling for Environmental Protection, G.R. Woolley, J. J. M. Goumans and P. J. Wainwright (editors), Pergamon, Amsterdam, vol. 1, pp. 178-185 (2000). ISBN: 0-08-043790-7.

(11) Guerrero, A., Goñi, S., Fernández, E. y Macías, A.: "Valorization of Fly Ash from Municipal Solid Waste Incineration Via Hydrothermal Treatment", Proceedings of the Seventh CANMET/ACI International Conference on Fly ash, Silica Fume, Slag and Natural Pozzolans in Concrete, vol. SP-199, 2001, pp. 295-306. ISBN: 0-87031-026-7.

(12) Guerrero, A., Goñi, S., Macías, A. y Fernández, E.: "Influence of synthesis temperature on the hydration of new cements from fly ash of municipal solid waste incineration", Proceedings of the CANMET/ACI International Symposium on Sustainable Development and Concrete Technology. Vol. SP-202, 2001, pp. 267-283. ISBN: 0-87031-041-0.

(13) Takuma, Y., Tsuchida, Y. y S. Uchida: "Characteristics and Hydration of Cement Produced from Ash from Incinerated Urban Garbage", Proceedings of the $10^{\text {th }}$ International Congress on the Chemistry of Cement, vol. 3, pp. 311-118, Gothenbirg, Sweden, 2-6 de junio de 1997.

(14) Takahashi, Hiroaki; Maruta, Toshihisa; Sakae, Kazumasa; Kasahara, Masaru. "Application of water-washed incineration fly ashes as cement raw material", Muki Materiaru, 5 (274) (1998), pp. 200-207.

(15) Kasahara, Masaru; Takahashi, Hiroaki; Sakae, Kazumasa; Maruta, Toshihisa: "Desalinizing of incineration ash and recycling as cement raw material by washing with water", Chichibu Onoda Kenkyu Hokoku, 49 (2) (1998), pp. 29-138. 